Journal of Clinical Investigation

Vol. 42, No. 4, 1963

\title{
IS HEMOGLOBIN AN ESSENTIAL STRUCTURAL COMPONENT OF HUMAN ERYTHROCYTE MEMBRANES? *
}

By ROBERT I. WEED, CLAUDE F. REED, AND GEORGE BERG

(From the Departments of Medicine and Radiation Biology, The University of Rochester School of Medicine and Dentistry, Rochester, N. Y.)

(Submitted for publication October 18, 1962; accepted December 27, 1962)

This investigation of human red cell membranes was undertaken in order to determine whether the presence of hemoglobin in the membrane is essential for maintenance of the membrane's structural integrity, which has been evaluated by studies of the shape, lipid content and composition, protein content, osmotic responsiveness, and certain enzymic activities of erythrocyte ghosts from which virtually all of the cellular hemoglobin had been removed.

Many studies have been done with red cell "ghosts," or posthemolytic residues, because such preparations offer the possibility of analyzing certain physiological, biochemical, electron microscopic, and immunologic properties attributable to the membranes themselves, apart from the intracellular contents. Representative techniques for preparation of red cell ghosts include hemolysis in distilled water, the effects of which were studied first by Bernstein and his associates (1), the freeze-thaw method described by Jorpes (2), the use of chemical lysins such as digitonin and saponin (3) and the use of $0.1 \%$ sodium chloride saturated with $\mathrm{CO}_{2}$ (4), both as described by Ponder, and the method of successive osmotic hemolysis proposed by Hillier and Hoffman (5). Recently, Danon, Nevo, and Marikovsky (6) have described a modification of the technique of Hillier and Hoffman which they have termed "gradual osmotic lysis." This method provides a high vield of ghosts that bear a remarkable resemblance

* This investigation was supported in part by U. S. Public Health Service research grant H-5241 (to Dr. Weed), in part by contract DA-49-007-MD-632 with the Medical Research and Development Division, Office of the Surgeon General, Department of the Army, and in part by the U. S. Atomic Energy Commission at the University of Rochester Atomic Energy Project, Rochester, N. Y. A preliminary report of these results was presented to the 9th Congress of the International Society of Hematology, Mexico City, September 17, 1962. to intact erythrocytes and are virtually free of hemoglobin. The hemoglobin content of these various ghost preparations, however, has varied from as much as $30 \%$ of the dry weight in the preparation of Bernstein and associates (1) down to $1.4 \%$ of the dry weight in the preparation of Danon, Nevo, and Marikovsky (6).

The presence of significant quantities of hemoglobin in ghosts raises the question of whether an observed property of such ghosts is truly confined to the membrane, or represents the activity of some residual, intracellular component. The variations between different preparations of ghosts further complicate comparison of properties. It is imposible, therefore, to define red cell ghosts except in terms of their preparation, since their composition varies widely with method of preparation. Therefore, the present investigation of whether hemoglobin plays an essential structural role in the membrane was carried out on ghosts prepared by the method of gradual osmotic lysis (6) because of the reproducibly low hemoglobin content of this preparation.

\section{METHODS}

Blood samples from hematologically normal, adult, male and female donors were collected into sufficient disodium ethylenediaminetetraacetic acid to yield a final plasma concentration of $5 \times 10^{-3} \mathrm{M}$. The blood was centrifuged at $1,750 \times g$ for 10 minutes, and the plasma and buffy coat were removed by aspiration. This procedure was repeated three times, and the cells were washed with $0.17 \mathrm{M}$ sodium chloride three times as well. After the third wash, a portion of the cells was resuspended in $0.17 \mathrm{M}$ sodium chloride at an hematocrit of 35 to $45 \%$. The red blood cell count of this suspension was determined, and samples were taken for lipid analyses. Another portion of the washed cells was resuspended at an hematocrit of $2.5 \%$ in a buffer containing $0.06 \mathrm{M}$ $\mathrm{NaCl}, 0.025 \mathrm{M} \mathrm{Na}_{2} \mathrm{HPO}_{4}$ and $0.008 \mathrm{M} \mathrm{KH}_{2} \mathrm{PO}_{4}$, at a $\mathrm{pH}$ of 7.2. The subsequent preparation of the erythrocyte ghosts was essentially as outlined by Danon, Nevo, and Marikovsky (6) with a few modifications. In order to avoid interference of inorganic phosphate with the lipid 
determinations, the final two washing procedures of the hemolysis process were conducted in 60 and 30 milliosmolar $\mathrm{NaCl}$ buffered at $\mathrm{pH} 7.2$ by 9.6 and $4.8 \mathrm{mM}$ Tris, respectively, rather than by the phosphate buffer when the ghosts were used for lipid analysis. Each of the hemolyzing and washing solutions contained $1 \mathrm{mM} \mathrm{Na}_{2}-$ EDTA, added before adjustment of the final osmolarity. The addition of EDTA distinctly enhanced the removal of hemoglobin. In addition, the ghosts were centrifuged in a refrigerated, Servall angle centrifuge at $9,000 \times g$ for 15 minutes rather than at $2,500 \times g$ for 5 minutes. The $9,000 \times g$ force gave a more satisfactory yield of ghosts than the lower forces, but centrifugation at forces greater than $9,000 \times g$ packed the ghosts so that their discrete separation and counting in the Coulter counter were unsatisfactory.

Measurements of the hemoglobin of the intact red cells were done by the method of Crosby, Munn, and Furth (7). The hemoglobin content of the ghost preparations was measured by the benzidine method of Bing and Baker (8) as modified by Dacie (9). Twenty $\mu 1$ of a ghost suspension containing between 3 and $5 \times 10^{6}$ ghosts per $\mathrm{mm}^{3}$ yielded a satisfactory range of color density by this method when diluted to a final volume of $10 \mathrm{ml}$. The absorption of the solution was measured at $515 \mathrm{~m} \mu$ on a Coleman Jr. spectrophotometer.

Nonhemoglobin protein content of hemoglobin-poor ghosts was determined by the micro-Kjeldahl technique of Kabat and Mayer (10). In addition, the nonhemoglobin protein concentration of ghosts was estimated by subtraction of the hemoglobin, lipid, and electrolyte content per cell from the total dry weight per cell.

The recovery of hemolyzed red cells as ghosts was quantitated by counting both intact red cells and ghosts with a Coulter model A electronic particle-counter. All lipid, protein, and enzymic activities were expressed on a per (ghost) cell basis. For counting, the threshold control of the Coulter counter was set at 4 , the aperture current at 8 , and the gain trim at 6 . Careful filtration of the $1 \%$ saline solution used for the dilution through a Millipore ${ }^{1}$ filter of $0.3 \mu$ pore size was necessary just before counting to reduce the background of the diluting medium enough to prevent interference with the ghost counting.

After the ghost count, samples of the ghost suspension for lipid analyses were centrifuged at $9,000 \times g$ and washed three times with $0.17 \mathrm{M} \mathrm{NaCl}$. The lipid analyses of the red blood cells and ghosts were carried out as described previously (11).

Glucose 6-phosphate dehydrogenase activity in intact red cells and in ghosts was measured by the method of Zinkham and Lenhard (12). A $0.3-\mathrm{ml}$ portion of the final ghost suspension containing from 3 to $5 \times 10^{8}$ cells per $\mathrm{mm}^{3}$ was added to make a final volume of $3 \mathrm{ml}$ containing glucose 6-phosphate, TPN, $\mathrm{MgCl}_{2}$, and Tris buffer in the amounts specified by the authors. The concentration of ghosts needed to provide measurable en-

\footnotetext{
1 Millipore Filter Corporation, Bedford, Mass.
}

zymic activity resulted in a slightly turbid solution. A check against any possible change in the optical density caused by settling of the ghosts was provided by shaking the cuvette containing ghosts and reagents, and rereading the optical density at the end of the recording period. There was no change in these control readings. The activity of the membrane glucose 6-phosphate dehydrogenase was determined immediately after preparation of the ghosts, since it decreased on standing; alternatively, $4 \times 10^{-4} \mathrm{M}$ TPN was added to stabilize the enzyme. Inactivation of the enzyme because of a stromal TPNase was described first by Carson, Schrier, and Alving (13), and stabilization by addition of TPN has been described and characterized by Kirkman $(14,15)$ and by Marks, Szeinberg, and Banks (16).

ATPase activity was measured by the method of Post, Merritt, Kinsolving, and Albright (17), modified in a number of details. Incubation was carried out at $37^{\circ} \mathrm{C}$ for 45 minutes (18) rather than for 60 minutes at $40^{\circ} \mathrm{C}$; the final incubation mixture was somewhat altered, since ghosts were suspended in the final hemolyzing solution (30 milliosmolar), and $0.5 \mathrm{ml}$ of this suspension was added to $2 \mathrm{ml}$ of other reagents in the incubating flask. The formula of the final incubation mixture was, in millimoles per liter : 80 imidazole-histidine buffer at $\mathrm{pH} 7.1,2$ $\mathrm{MgCl}_{2}, 2 \mathrm{ATP}, 1$ Tris buffer (from ghost suspension), 0.2 EDTA (from ghost suspension), $80 \mathrm{NaCl}$, and 0 or 33 $\mathrm{KCl}$. There were no antibiotics in this mixture. Inorganic phosphate was determined by Rothstein's modification (19) of the Fiske-Subbarow method. Enzyme activity was measured as micromoles of orthophosphate phosphorus released per hour. Activity without added potassium was called "residual ATPase," whereas the difference between activity with potassium and that without potassium was called " $\left(\mathrm{Na}^{+}+\mathrm{K}^{+}\right)$-dependent ATPase" (17). The following properties of the two ATPases were measured : 1) activity per cell and activity per dry weight, 2) inhibition or activation by $\left.1.8 \times 10^{-4} \mathrm{M} \mathrm{Ca}^{++}(18), 3\right)$ inhibition by ccncentrations of ouabain from $1 \times 10^{-6}$ to $\left.1 \times 10^{-8} \mathrm{M}, 4\right)$ differences of activity between ghost suspensions that were stored frozen and suspensions tested without freezing, and 5) effects of changes of the method of hemolysis on the activity of the enzymes. The changes were: addition of antibiotics ( $100 \mathrm{U}$ per $\mathrm{ml}$ of penicillin and $0.1 \mathrm{mg}$ per $\mathrm{ml}$ of streptomycin) to the hemolyzing solutions; omission of EDTA from all solutions, with replacement by heparin in the initial steps for anticoagulation of the blood sample; contamination of red blood cell ghosts with white blood cell ghosts by not removing the buffy coat after centrifugation of the whole blood; and finally, assay of the ATPase activity after hemolysis by the method of Post and co-workers (17).

Osmotic responsiveness of ghosts prepared in the standard manner described in this report was measured by the addition of $1 \mathrm{vol}$ of $66 \% \mathrm{vol} / \mathrm{vol}$ suspension of ghosts in 30 milliosmolar buffer to 1 vol of buffered ( $\mathrm{pH} 7.4$ ) sodium chloride at varying osmolar concentrations. The initial ghost count was obtained with the Coulter counter, the packed cell volume estimated with the International 
microhematocrit centrifuge $(10,000 \times g$ for 30 minutes $)$, and the final extracellular osmolarity determined by measurement of the freezing point depression with a Fisk osmometer.

\section{RESULTS}

Cell recovery. The recovery of ghosts from red cells was determined by comparing the initial red cell count with the ghost count at the end of the hemolytic process. The ghost count values in each case represented a mean value of counts taken from four of eight tubes containing all the ghosts for counting, before final pooling of the contents for chemical determinations. Removal of the ghosts for counting at this point was advantageous in that clumping occurred in the highly concentrated, pooled suspension of ghosts if it was permitted to stand, and such clumping gives a falsely low count per unit volume. Immediate counting of the pooled suspension of ghosts, however, was found to be satisfactory. For ten experiments, the mean recovery of ghosts from intact red blood cells was $97.5 \%$ with a range of 93.4 to $102.6 \%$. This value agreed well with the figures quoted by Danon, Nevo, and Marikovsky (6) and confirms the derivation of the final preparation of ghosts from a representative sample of the initial, intact, erythrocyte suspension.

Hemoglobin content. The ghosts appeared cream-colored in suspension and were found to be virtually free of hemoglobin. As indicated in Table I, the mean content of hemoglobin per ghost was $0.015 \times 10^{-12} \mathrm{~g}$ per cell, or $0.05 \%$ of that contained in the intact cell. The decrease of hemoglobin content as a function of the number of washes is a first-order process down to and including the lowest values of hemoglobin that can be measured. This indicates that there is no evidence for binding of hemoglobin to the membrane under the conditions employed. Finally, the loss of so much hemoglobin suggests that a similar loss

TABLE I

Hemoglobin content per cell of red blood cells and ghosts

\begin{tabular}{lcc}
\hline & Red blood cells $(\mathrm{n}=14)$ & Ghosts $(\mathrm{n}=24)$ \\
\hline $\begin{array}{c}\text { Hemoglobin, } \\
\mathrm{g} \times 10^{-12}\end{array}$ & $30.99 \pm 0.12(\mathrm{SD})$ & $0.015 \pm 0.009$ (SD) \\
$\begin{array}{c}\text { Hemoglobin, } \% \\
\text { dry weight }\end{array}$ & 97 & 1.4 \\
\hline
\end{tabular}

TABLE II

Lipid content per cell of intact red blood cells and ghosts*

\begin{tabular}{|c|c|c|c|}
\hline Lipids & Red blood cells & Ghosts & $\mathrm{p}$ \\
\hline Total lipid, $\mathrm{g} \times 10^{-18}$ & $4.91 \pm 0.33$ & $4.95 \pm 0.33$ & $>0.60$ \\
\hline Total cholesterol, $\mathrm{g} \times 10^{-13}$ & $1.13 \pm 0.08$ & $1.08 \pm 0.06$ & $>0.05$ \\
\hline $\begin{array}{l}\text { Total lipid phosphorus, } \\
\mu \mathrm{g} \times 10^{-9}\end{array}$ & $11.89 \pm 0.68$ & $11.47 \pm 0.85$ & $>0.40$ \\
\hline \multicolumn{4}{|l|}{$\begin{array}{l}\text { Individual phospholipids, } † \\
\mu \mathrm{g} P \times 10^{-9}\end{array}$} \\
\hline Sphingomyelin & $3.12 \pm 0.14$ & $2.91 \pm 0.26$ & $>0.05$ \\
\hline Lecithin & $3.37 \pm 0.19$ & $3.28 \pm 0.22$ & $>0.40$ \\
\hline Phosphatidyl serine & $1.79 \pm 0.22$ & $1.84 \pm 0.09$ & $>0.40$ \\
\hline Phosphatidyl ethanolamine & $2.39 \pm 0.26$ & $2.31 \pm 0.23$ & $>.040$ \\
\hline Other $\ddagger$ & $1.22 \pm 0.07$ & $1.13 \pm 0.07$ & $>0.40$ \\
\hline
\end{tabular}

* Mean values $\pm \mathrm{SD}$ are given for preparations from nine hematologically normal subjects. p was determined by $t$ test (20). tPlasmalogens, where present, were analyzed with the parent

$\ddagger$ compounds.
$\ddagger$ This includes lysolecithin, inositol phosphatide, and polyglycero phosphatide, which together constitute about $10 \%$ of the total lipid phosphorus of the red blood cell (11)

of other soluble-phase constituents of the same or lower molecular size occurred simultaneously.

Lipid content of the ghosts. Table II summarizes the results of nine experiments in which the ghost lipids were compared with the lipids of the red blood cells from which they were derived. Because the ghosts were washed three times after counting, whereas the intact cells were not, a small bias in favor of lower lipid values per ghost was introduced. Nonetheless, there are no differences significant at a confidence level of $5 \%$ in any of the parameters studied. Ponder (3) has shown that myelin forms, which contain lipid, are lost from the cell during preparation of ghosts. Such loss must be very small, however, and less than the variability of the lipid method itself, since it is impossible to show that any significant loss of the cellular lipid occurred by this technique of hemolysis, in spite of the virtually complete removal of hemoglobin.

Nonhemoglobin protein content. Micro-Kjeldahl measurements of the ghost proteins, corrected for the small amount of residual hemoglobin, yielded a mean value for nonhemoglobin protein of $5.61 \pm 0.21(\mathrm{SE}) \times 10^{-13} \mathrm{~g}$ per cell, $\mathrm{n}=10$. A similar value of $5.81 \pm 0.21(\mathrm{SE}) \times$ $10^{-13} \mathrm{~g}$ per cell, $\mathrm{n}=9$, was obtained by subtraction of the weight of lipid, hemoglobin, and electrolyte from the total dry weight of the ghosts. The nonhemoglobin protein content of "red" ghosts analyzed after the initial hemolytic step was also 
estimated by subtraction of other components from the total dry weight. These "red" ghosts contained $5.32 \pm 0.42$ (SE) g per cell, $\mathrm{n}=4$, of nonhemoglobin stromal proteins and 4 to $5 \times$ $10^{-13} \mathrm{~g}$ hemoglobin per cell, or approximately 30 to 40 times that in the "white" ghosts. Although there is significant variability in the nonhemoglobin protein determination, there is obviously no significant loss of stromal protein during the final stages of ghost preparation. Because the stromal protein constitutes such a small fraction of the total protein of the intact cell and can be determined only by subtraction of hemoglobin, which accounts for $97 \%$ of the cell's dry weight, stromal protein was not measured in the intact cell.

Glucose 6-phosphate dehydrogenase activity of the ghosts was assayed and compared with the total activity of the whole red cells. Based on twelve determinations, the red cells were found to have an activity of $2.13 \pm 0.29(\mathrm{SD}) \times 10^{-9} \mathrm{OD}$ $\mathrm{U}$ per 5 minutes per cell, whereas the membranes have an activity of $2.91 \pm 1.04(\mathrm{SD}) \times 10^{-11} \mathrm{OD}$ $\mathrm{U}$ per 5 minutes per cell. It can be seen that the membrane has approximately $1.4 \%$ of the glucose 6-phosphate dehydrogenase activity found in the whole cell. Studies of the decline of this enzymic activity after successive washings of the ghosts demonstrated a curve showing two components, one decreasing rapidly in parallel with hemoglobin content of the cells, and another decreasing at a much slower rate than hemoglobin. These results indicate that a small residual glucose 6-phosphate dehydrogenase activity is associated with ghost membranes in spite of the loss of $99.95 \%$ of the hemoglobin. Enzymic activity rather than amount of enzyme has been measured, so that it is not possible to say whether the residual activity found is enzyme bound to the membrane or whether the small amount of enzyme found in association with the membrane may have greater activity than the glucose 6-phosphate dehydrogenase present in stroma-free hemolysate.

Although ATPase is thought to be localized in the red cell membrane, preparations such as that of Post and co-workers (17) have had as much as $59 \%$ by weight of residual hemoglobin in ghosts and $10 \%$ by weight of residual hemoglobin in purified "enzyme." It was of interest, therefore, to study ATPase activity in a preparation containing virtually no hemoglobin. Some of the properties of the ATPase activities of this preparation are summarized in Table III. ATPase activity is expressed both in relation to dry weight and on a per cell basis. Assays performed on

TABLE III

Adenosine triphosphatase activity of red blood cell ghosts*

\begin{tabular}{|c|c|c|c|}
\hline Ghost preparation $\dagger$ & Units of activity & $\begin{array}{c}\text { Activity of } \\
\left(\begin{array}{c}\left.\mathrm{Na}^{+}+\mathrm{K}^{+}\right)- \\
\text {dependent } \\
\text { ATPase }\end{array}\right.\end{array}$ & $\begin{array}{l}\text { Activity of } \\
\text { residual ATPase }\end{array}$ \\
\hline Fresh suspension & $\begin{array}{l}10^{-2} \mu \text { moles } \mathrm{P} / \\
\text { mg dry wt } X \text { hours }\end{array}$ & $\begin{array}{c}21.0 \pm 0.37 \\
\quad(\mathrm{n}=8)\end{array}$ & $\begin{array}{c}12.6 \pm 0.23 \\
(\mathrm{n}=8)\end{array}$ \\
\hline Fresh suspension & $\begin{array}{l}10^{-10} \mu \text { moles } \mathrm{P} / \\
\text { cell } \times \text { hours }\end{array}$ & $\begin{array}{l}2.02 \pm 0.40 \\
(\mathrm{n}=15)\end{array}$ & $\begin{array}{c}1.52 \pm 0.24 \\
(\mathrm{n}=15)\end{array}$ \\
\hline Frozen suspension & $\begin{array}{l}10^{-10} \mu \text { moles } \mathrm{P} / \\
\text { cell } \times \text { hours }\end{array}$ & $\begin{array}{c}1.78 \pm 0.33 \\
(n=9)\end{array}$ & $\begin{array}{c}1.60 \pm 0.21 \\
(\mathrm{n}=9)\end{array}$ \\
\hline $\begin{array}{l}\text { Fresh suspension contaminated } \\
\text { with white blood cells }\end{array}$ & $\begin{array}{l}10^{-10} \mu \text { moles } \mathrm{P} / \\
\text { cell } \times \text { hours }\end{array}$ & $\begin{array}{c}1.06 \pm 0.36 \\
(\mathrm{n}=5)\end{array}$ & $\begin{array}{l}1.41 \pm 0.33 \\
(\mathrm{n}=5)\end{array}$ \\
\hline $\begin{array}{l}\text { Frozen suspension with } \\
1.8 \times 10^{-4} \mathrm{M} \mathrm{Ca}^{++}\end{array}$ & $\begin{array}{l}\text { Activity with additive as } \% \\
\text { of activity without additive }\end{array}$ & $\begin{array}{l}68 \pm 0.73 \\
(\mathrm{n}=2)\end{array}$ & $\begin{array}{l}331,320 \\
(\mathrm{n}=2)\end{array}$ \\
\hline $\begin{array}{l}\text { Frozen suspension with } \\
1 \times 10^{-7} \mathrm{M} \text { ouabain }\end{array}$ & $\begin{array}{l}\text { Activity with additive as } \% \\
\text { of activity without additive }\end{array}$ & $\begin{array}{c}83.5 \pm 2.9 \\
(n=4)\end{array}$ & $\begin{aligned} 105 & \pm 11.6 \\
(\mathrm{n} & =4)\end{aligned}$ \\
\hline $\begin{array}{l}\text { "Pink" membranes } \ddagger \text { with } \\
1 \times 10^{-\tau} \mathrm{M} \text { ouabain }\end{array}$ & $\begin{array}{l}\text { Activity with additive as } \% \\
\text { of activity without additive }\end{array}$ & $\begin{array}{l}43 \pm 3.28 \\
(\mathrm{n}=4)\end{array}$ & $\begin{aligned} 103 & \pm 4.4 \\
(\mathrm{n} & =4)\end{aligned}$ \\
\hline
\end{tabular}

* Mean values $\pm 1 \mathrm{SD}$ are given, except where only two experiments were done. Control values for experiments on the effect of additives or hemoglobin are included in the mean value for the frozen suspension; values for determinations with additives are expressed as a percentage of control values on the same sample run in parallel, simultaneously.

$\dagger$ Fresh suspensions were assayed immediately after preparation; frozen suspensions (frozen immediately after preparation) were thawed and assayed later.

$\ddagger$ Prepared by the same method as the "enzyme" of Post and co-workers (17). 
stored ghosts revealed a selective decrease of $10 \%$ in the $\left(\mathrm{Na}^{+}+\mathrm{K}^{+}\right)$-dependent ATPase activity after freezing and thawing as compared with assays of this activity in fresh ghosts. This decrease was small enough so that frozen preparations were used for comparing the effects of hemoglobin and additives, as indicated in Table III. There was, however, inhibition of both the residual and $\left(\mathrm{Na}^{+}\right.$ $+\mathrm{K}^{+}$)-dependent ATPase activities to $60 \%$ of the control values when antibiotics (100 $\mathrm{U}$ per $\mathrm{ml}$ penicillin and $0.1 \mathrm{mg}$ per $\mathrm{ml}$ streptomycin) were added to the hemolyzing solutions at any point. In addition, the presence of contaminating white blood cells ( 1 white cell per 1,000 red cells) significantly inhibited the $\left(\mathrm{Na}^{+}+\mathrm{K}^{+}\right)$-dependent ATPase activity, but not the residual ATPase activity, as indicated in Table III. Thus, exclusion of antibiotics and careful removal of white blood cells were essential for optimal enzyme activity.

Table III indicates that the $\left(\mathrm{Na}^{+}+\mathrm{K}^{+}\right)$-dependent ATPase activity of the present preparation is similar to that in the preparation described by Post and co-workers (17) as "enzyme," but the ratio of $\left(\mathrm{Na}^{+}+\mathrm{K}^{+}\right)$-dependent activity to residual activity was higher in ghosts prepared by the present method. Ouabain inhibited only the $\left(\mathrm{Na}^{+}+\mathrm{K}^{+}\right)$-dependent ATPase activity of our preparation, as Post and co-workers (17) found previously. The 50\% inhibitory concentration of ouabain, as determined in four independent experiments using frozen ghosts, was $4.6 \pm 1.28$ (SD) $\times 10^{-7} \mathrm{M}$, or approximately $3 \times 10^{5}$ molecules of ouabain per ghost cell. In contrast to these findings, in purified "enzyme" prepared by the method of Post and co-workers (17), the $\left(\mathrm{Na}^{+}\right.$ $+\mathrm{K}^{+}$)-dependent ATPase activity was twice as sensitive to ouabain, as indicated in Table III. Our values for ouabain inhibition of purified "enzyme" prepared by the method of Post and coworkers (17) agree with the original results of those authors.

As indicated in Table III, when $\mathrm{Ca}^{++}$was added to ghosts prepared by the present method, a threefold increase in residual activity was observed together with a partial inhibition of $\left(\mathrm{Na}^{+}+\mathrm{K}^{+}\right)$-dependent ATPase. Similarly, ghosts prepared and assayed without the addition of EDTA were found to contain twice as much residual ATPase activity as ghosts prepared in the standard fashion in the presence of EDTA. No difference in $\left(\mathrm{Na}^{+}+\right.$ $\mathrm{K}^{+}$)-ATPase activity was noted when ghosts were prepared without EDTA.

Osmotic responsiveness. Figure 1 illustrates the osmotic responsiveness of ghosts, plotted according to Ponder and Barreto's method of analysis (21). That osmotic responsiveness does exist

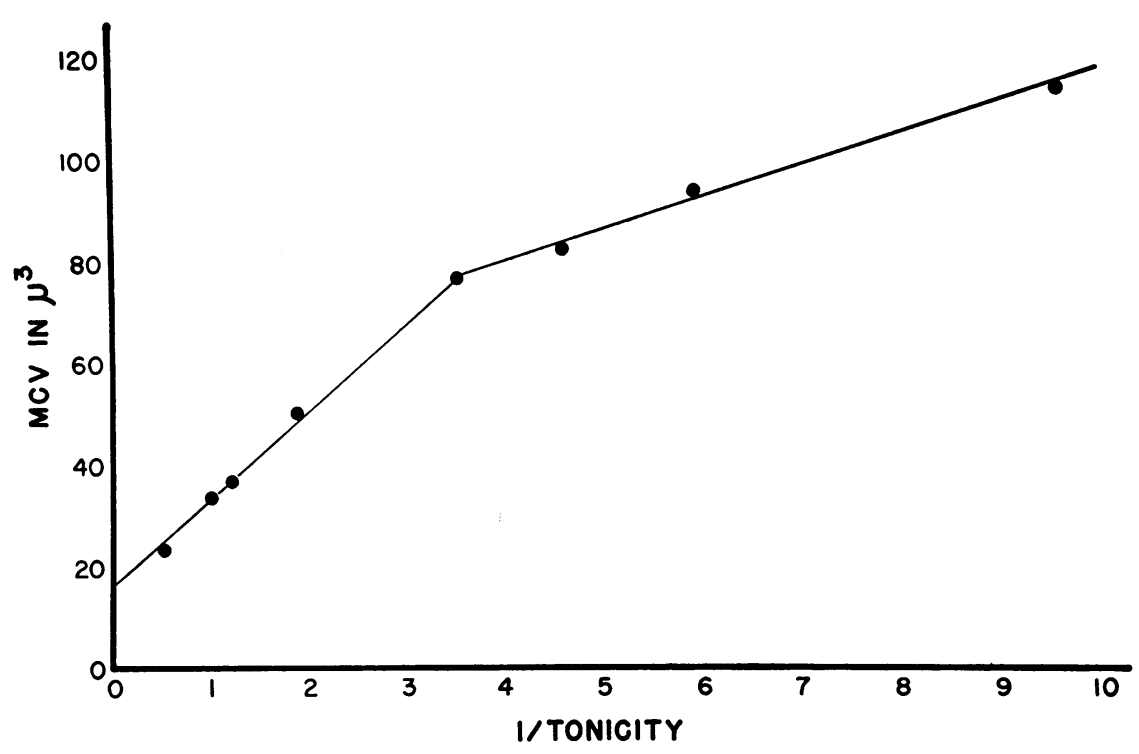

Fig. 1. Osmotic responsiveness of human erythrocyte ghosts cells. Mean corpuscular volume of ghosts after addition of buffered sodium chloride is plotted against final extracellular tonicity. $310 \mathrm{mOsm}$ per $\mathrm{L}$ was taken as 1 . 

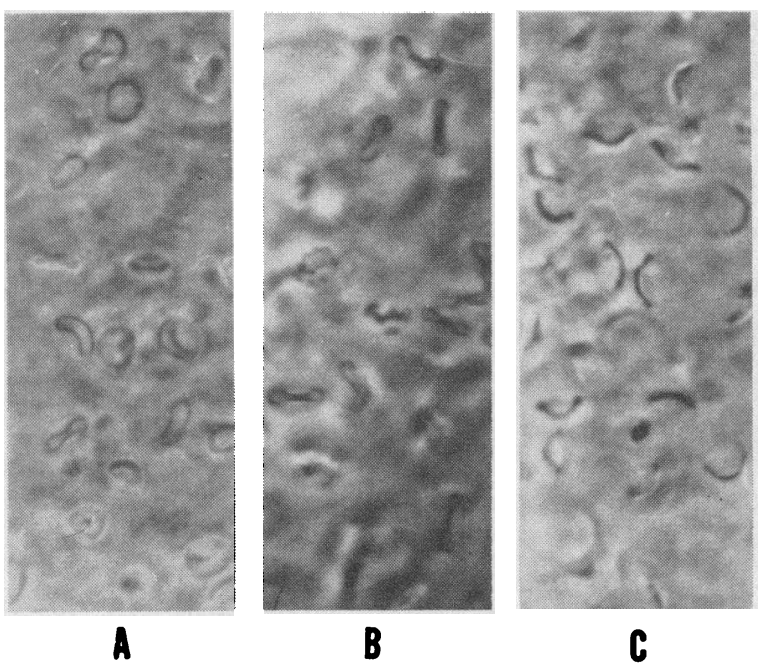

Fig. 2. Appearance of human erythrocyte ghost CELLS IN SOLUTIONS OF VARYING TONICITY. All solutions are sodium chloride Tris buffer at $\mathrm{pH}$ 7.4: A, 30 mOsm per L; B, 300 mOsm per L; and C, 800 mOsm per L.

indicates definite physical integrity of the membrane. The linear portion of the curve representing behavior analogous to that of a perfect osmometer is limited, however, to changes in volume occurring at tonicities greater than $100 \mathrm{mOsm}$ per L. Such osmotic responsiveness has been noted in "pink" ghosts by Teorell (22), Stein (23), and Ponder and Barreto (21). Ponder and Barreto, however, have pointed out that although a decrease in mean ghost cell volume occurs when ghosts are transferred from solutions of $0.15 \%$ chloride to solutions $0.3,1$, and 1.7 times the tonicity of plasma, such a change does not represent a uniform response of all cells. The suspensions placed in higher tonicity may contain discs, spheres, and crenated forms in varying percentages, and consequently, Ponder and Barreto have questioned whether these changes should be considered true osmotic responsiveness. In our preparation, as illustrated in Figure 2, ghost cells are seen in 30,300 , and 800 milliosmolar Tris buffers. A1though there are some crenated cells at intermediate tonicities, very few are seen at the low, hemolytic, 30 milliosmolar concentration of solute and at the very high, 800 milliosmolar concentration, in which the cells appear as very flat discs and have obviously responded to the increased tonicity more than those in 300 milliosmolar buffer. The crenation can be minimized by use of siliconized slides and cover slips, by use of Tris instead of a phosphate buffer, and by immediate examination, since the number of crenated forms appears to increase with time.

\section{DISCUSSION}

The technique of gradual osmotic hemolysis produces erythrocyte ghost cells that remarkably resemble intact cells and that can be considered a satisfactory membrane preparation by virtue of their low hemoglobin content and retention of all the lipid of the intact cells. In addition, the retention of osmotic responsiveness must indicate restoration of a significant degree of the integrity of the membrane after hemolysis.

Before considering loss of lipid from ghosts, it is important to recall that although Lovelock (24) has suggested substantial loss of lipid from intact red cells after washing with sodium chloride, studies of red cell cholesterol by Brun (25) and of both cholesterol and phospholipids by Reed, Swisher, Marinetti, and Eden (11) have not confirmed such a loss. Turning to human red cell ghosts, Erickson and co-workers (26) were unable to demonstrate loss of the cellular lipids during the preparation of red cell ghosts. When ghosts were prepared by the present technique, no evidence of loss of lipid could be demonstrated. It is, in fact, remarkable that under the proper circumstances red cells can undergo hemolysis with loss of $97 \%$ of their contents by weight, yet retain all of their membrane lipid and even repair defects in continuity of the membrane that are large enough to permit egress of hemoglobin molecules.

There seems little question that, together with structural proteins and lipids. hemoglobin is associated with the red cell membrane. In fact, Bessis, Bricka, Breton-Gorius, and Tabuis (27) have demonstrated the presence of hemoglobin in myelin forms arising from the cell surface, and Ponder (28) has suggested that hemoglobin molecules in the membrane are probably relatively highly oriented with respect to the lipoproteins so that they form part of the ultrastructure of the cell. Since hemoglobin is associated with the membrane, attempts to establish whether it exists there as an essential structural component have centered about the question of whether hemoglobin is tightly bound to other membrane constituents. Ander- 
son and Turner (29), who prepared ghosts by distilled water hemolysis, found that attempts to reduce the residual hemoglobin content of ghosts to less than $3 \%$ of that in the intact cell resulted in a substantial loss of lipid phosphorus. This suggested to them that hemoglobin was bound to the lipid and played an important structural role in the membrane. The value obtained by Anderson and Turner for total lipid phosphorus in the intact cell is about half that obtained by other workers (11,30-33). Furthermore, Anderson and Turner used the original method for lipid extraction described by Folch and co-workers (34) in which the initial chloroform-methanol extract of the tissue is washed with a large volume of water. The large loss of lipid phosphorus observed by Anderson and Turner in ghost preparations having less than $3 \%$ of the initial hemoglobin may therefore be due to differences in these preparations in "lipid distribution altering factors" (35), rather than to a true loss of lipid phosphorus from the membrane.

Hoffman (36), on the other hand, through the use of extracellular radioactive hemoglobin, has demonstrated equilibrium between environmental hemoglobin and all of the cellular hemoglobin at the time of hemolysis in the presence of low concentrations of sodium chloride. The present studies, using the method of gradual osmotic lysis, also demonstrate that hemoglobin is not tightly bound to the membrane lipids or lipoproteins and can be removed without loss of lipid. In addition, the preservation of cell shape by the ghosts and restoration of a degree of impermeability of the membrane indicate that membrane hemoglobin is not essential for osmotic responsiveness.

Finally, these studies have demonstrated that the presence of hemoglobin in association with the membrane is not essential for two enzymic activities of the membrane, glucose 6-phosphate dehydrogenase and $\left(\mathrm{Na}^{+}+\mathrm{K}^{+}\right)$-dependent ATPase. The $\left(\mathrm{Na}^{+}+\mathrm{K}^{+}\right)$-dependent ATPase activity, in particular, was unchanged in hemoglobin-free "white" ghosts as compared with "pink" ghosts containing hemoglobin. In fact, the $\left(\mathrm{Na}^{+}+\mathrm{K}^{+}\right)$dependent activity of "white" ghosts was more resistant to ouabain, as if the presence of hemoglobin could sensitize the membrane to cardiac glycosides. Residual ATPase, the third enzymic activity tested, appeared to lose activity with pro- gressive removal of hemoglobin. Our studies of calcium activation and of the effects of EDTA on residual ATPase agree with the finding of Dunham and Glynn (18) that endogenous calcium activates that enzyme. Direct measurements of membrane calcium have not been feasible, and consequently we cannot exclude the possibility that it is the removal of calcium in the course of hemolysis rather than the removal of hemoglobin which accounted for the lowered residual ATPase activity of the present preparation.

SUMMARY

1) Preparation of ghosts from normal human erythrocytes by the method of gradual osmotic lysis permits quantitative recovery of cells from which $99.95 \%$ of the hemoglobin has been removed. 2) Ghosts prepared in the fashion described $a$ ) appear to have glucose 6-phosphate dehydrogenase and $\left(\mathrm{Na}^{+}+\mathrm{K}^{+}\right)$-dependent adenosine triphosphatase activities independent of their hemoglobin content, $b$ ) retain all the cholesterol and phospholipid content of the cells from which they were prepared, c) retain the biconcave disc shape of intact erythrocytes, and $d$ ) retain osmotic responsiveness. 3) On the basis of these studies, hemoglobin has not been found to be an essential structural component of the human erythrocyte membrane.

\section{ACKNOWLEDGMENTS}

The authors wish to express their appreciation to Dr. Douglas Johnstone for the Kjeldahl determinations and to Miss Carol Berger, Mrs. Brenda Chapman, Mrs. Marion Murphy, Mrs. Geraldine Roberts, and Mrs. Martha Vaules for their help and technical assistance.

\section{REFERENCES}

1. Bernstein, S. S., R. L. Jones, B. N. Erickson, H. H. Williams, I. Avrin, and I. G. Macy. A method for the preparation of post hemolytic residue or stroma of erythrocytes. J. biol. Chem. 1938, 122, 507.

2. Jorpes, E. The protein component of the erythrocyte membrane or stroma. Biochem. J. 1932, 26, 1488.

3. Ponder, E. Red cell structure and its breakdown. Protoplasmatologia: Handbuch der protoplasmaforschung. Vienna, Springer, 1955, 10, 43.

4. Ponder, E. On properties of the red cell ghost. I. Volume and shape changes during haemolysis and "reversible of haemolysis." J. exp. Biol. 1942, 18, 257. 
5. Hillier, J., and J. F. Hoffman. On the ultrastructure of the plasma membrane as determined by the electron microscope. J. cell. comp. Physiol. 1953, 42, 203.

6. Danon, D., A. Nevo, and Y. Marikovsky. Preparation of erythrocyte ghosts by gradual haemolysis in hypotonic aqueous solution. Bull. Res. Coun. Israel E 1956, 6, 36.

7. Crosby, W. H., J. F. Munn, and F. W. Furth. Standardizing a method for clinical hemoglobinometry. U. S. armed Forces med. J. 1954, 5, 693.

8. Bing, F. C., and R. W. Baker. The determination of hemoglobin in minute amounts of blood by Wu's method. J. biol. Chem. 1931, 92, 589.

9. Dacie, J. V. Practical Haematology, 2nd Ed. London, J. and A. Churchill, 1956, p. 140.

10. Kabat, E. A., and M. M. Mayer. Experimental Immunochemistry. Springfield, Ill., Charles C Thomas, 1961, p. 480.

11. Reed, C. F., S. N. Swisher, G. V. Marinetti, and E. G. Eden. Studies of the lipids of the erythrocyte. I. Quantitative analysis of the lipids of normal human red blood cells. J. Lab. clin. Med. 1960, 56, 281.

12. Zinkham, W. H. An in-vitro abnormality of glutathione metabolism in erythrocytes from normal newborns; mechanism and clinical significance. J. Pediat. 1959, 23, 18.

13. Carson, P. E., S. L. Schrier, and A. S. Alving. Inactivation of glucose-6-phosphate dehydrogenase in human erythrocytes (abstract). J. Lab. clin. Med. 1956, 48, 794.

14. Kirkman, H. N. Characterization of partially purified glucose-6-phosphate dehydrogenase from normal and primaquine-sensitive erythrocytes (abstract). Fed. Proc. 1959, 18, 261.

15. Kirkman, H. N. Glucose-6-phosphate dehydrogenase from human erythrocytes. I. Further purification and characterization. J. biol. Chem. 1962, 237, 2364.

16. Marks, P. A., A. Szeinberg, and J. Banks. Erythrocyte glucose-6-phosphate dehydrogenase of normal and mutant human subjects. J. biol. Chem. 1961, 236, 10.

17. Post, R. L., C. R. Merritt, C. R. Kinsolving, and C. D. Albright. Membrane adenosine triphosphatase as a participant in the active transport of sodium and potassium in the human erythrocyte. J. biol. Chem. 1960, 235, 1796.

18. Dunham, E. T., and I. M. Glynn. Adenosinetriphosphatase activity and the active movements of alkali metal ions. J. Physiol. 1961, 156, 274.

19. Berg, G. G., and L. H. Gordon. Presence of trimetaphosphatase in the intestinal mucosa and properties of the enzyme. J. Histochem. Cytochem. $1960,8,85$.

20. Dixon, W. J., and F. J. Massey. Introduction to Statistical Analysis, 2nd ed. New York, McGrawHill, 1957, p. 121.

21. Ponder, E., and D. Barreto. The behavior, as regards shape and volume, of human red cell ghosts in fresh and in stored blood. Blood 1957, 12, 1016.

22. Teorell, T. Permeability properties of erythrocyte ghosts. J. gen. Physiol. 1952, 35, 669.

23. Stein, W. D. The permeability of erythrocyte ghosts. Exp. Cell Res. 1956, 11, 232.

24. Lovelock, J. E. The physical instability of human red blood cells. Biochem. J. 1955, 60, 692.

25. Brun, G. C. Cholesterol content of the red blood cells in man. Acta med. Scand. 1939, suppl. 99, 1.

26. Erickson, B. N., H. W. Williams, S. S. Bernstein, I. Avrin, R. L. Jones, and I. G. Macy. Lipid distribution of posthemolytic residue or stroma of erythrocytes. J. biol. Chem. 1938, 122, 515.

27. Bessis, M., M. Bricka, J. Breton-Gorius, and J. Tabuis. New observations on sickle cells with special reference to their agglutinability. Blood 1954, 9, 39.

28. Ponder, E. Red cell structure and its breakdown. Protoplasmatologia: Handbuch der protoplasmaforschung. Vienna, Springer, 1955, 10, 53.

29. Anderson, H. M., and J. C. Turner. Relation of hemoglobin to the red cell membrane. J. clin. Invest. $1960,39,1$.

30. Axelrod, J., J. Reichenthal, and B. B. Brodie. The direct determination of phosphatidyl ethanolamine and phosphatidyl serine in plasma and red blood cells. J. biol. Chem. 1953, 204, 903.

31. Phillips, G. B., and N. S. Roome. Phospholipids of human red blood cells. Proc. Soc. exp. Biol. (N. Y.) 1959, 100, 489.

32. Westerman, M. P., L. E. Pierce, and W. N. Jensen. Red cell and plasma lipid studies in sickle cell anemia (abstract). Blood 1960, 15, 422.

33. Farquhar, J. W. Human erythrocyte phosphoglycerides. I. Quantification of plasmalogens, fatty acids and fatty aldehydes. Biochim. biophys. Acta (Amst.) 1962, 60, 80.

34. Folch, H., I. Ascoli, M. Lees, J. A. Meath, and F. N. LeBaron. Preparation of lipide extracts from brain tissue. J. biol. Chem. 1951, 191, 833.

35. Folch, J., M. Lees, and G. H. S. Stanley. A simple method for the isolation and purification of total lipides from animal tissues. J. biol. Chem. 1957, 226, 497.

36. Hoffman, J. F. Physiological characterization of human red blood cell ghosts. J. gen. Physiol. 1958, 42, 9. 